\title{
Before Guantanamo or Abu Ghraib were the Black Panthers \\ Mumia Abu-Jamal
}

Tong before the words "Guantanamo" and "Abu Ghraib" entered common -American usage as reference points for government torture, there were several young Black men who knew something about the subject.

The year was 1973, and among 13 "Black militants" arrested in a New Orleans sweep were three men: Harold Taylor, John Bowman and Ruben Scott. The three were beaten, tortured and interrogated by New Orleans cops, acting on tips supplied by San Francisco police.

The men were stripped, beaten with blunt objects, blindfolded, shocked on their private parts by electric cattle prods, punched and kicked and had wool blankets soaked in boiling water thrown over them. Under such torture, the three gave false confessions concerning the shooting of a San Francisco cop in 1971. The charges were eventually thrown out after a judge in California found that the prosecution had failed to tell a grand jury that the confessions were exacted under torture. Today, over 30 years later, Taylor, Bowman and Scott have again been called before a grand jury in an effort to resurrect what was dismissed in 1976.

Imagine what these men thought when they heard about the US government torture chambers in Guantanamo Bay and Abu Ghraib in Iraq. The names may have been different, but the grim reality was the same. Today, these men have formed the "Committee for the Defense of Human Rights" to try to teach folks about what happened so many years ago and what is happening now. Their living example teaches us that history repeats itself but in worse, more repressive forms.

That's because their first conflicts with the State took place under the aegis of the since discredited COINTELPRO (Counterintelligence Program). That program, after the famous Church Committee hearings in the Senate (1976), was declared illegal and a violation of the Constitution.

Today, thanks to a Congress weakened by corporate largesse and frightened by September 11, the same things that were illegal in the 1970s have been all but resurrected and legalized under the notorious Patriot Act. What we are seeing all across the nation is the emergence of what the late Black Panther Minister of Information, Eldridge Cleaver, called "Yankee Doodle fascism": the rise of corporate and state power to attack dissidents and destroy even the pretension of civil rights. 
I say pretension because the events I discussed earlier happened in 1973, yet none of the torturers, the violators, the criminals in blue ever were sanctioned for their violations of state, federal and, indeed, international law. Not one.

Think of this: The murderers of Fred Hampton Sr., those malevolent minions of the state who crept into his home and shot him dead-as he slept! - have never served a day, a minute, a second in jail for this most premeditated of murders, planned at the highest levels of government.

The roots of Guantanamo, of Abu Ghraib, of Bagram Air Force Base, of US secret torture chambers operating all around the world are deep in American life and its long war against Black life and liberation. Is it mere coincidence that the most notorious guard at Abu Ghraib worked right here in the US, here in Pennsylvania, here in SCI-Greene for over six years before exporting his brand of "corrections" to the poor slobs who met him in Iraq?

Back in the 1960s and 1970s, Panthers and others spoke about fascism, but it had an edge of hyperbole, of radical speech, to move people beyond their complacency. Several years ago, a political scientist who studied fascism on three continents came to some pretty sobering conclusions. According to Dr. Lawrence Britt, fascist states have 14 characteristics in common. They are, briefly: 1) powerful nationalism; 2) disdain for human rights; 3) scapegoating to unify against 'enemies'; 4) military supremacy; 5) rampant sexism; 6) controlled mass media; 7) national security obsession; 8) government religiosity; 9) rise of corporate power; 10) suppression of labor; 11) anti-intellectualism; 12) obsession with punishment; 13) deep corruption and cronyism; and 14) fraudulent elections. How many of these features are reflected daily in the national life of the United States?

What happens abroad is a grim reflection of what has happened here, albeit quietly. The tortures of Taylor, Bowman and Scott won't be featured stories on Nightline nor on the (supposedly "liberal") NPR. (Remember the characteristic of a "controlled mass media"?)

What happens overseas has its genesis in the monstrous history of what happened here: genocide, mass terrorism and racist exploitation (also known as "slavery"), land theft and carnage. All of these horrors have been echoed abroad, shadows of hatred, xenophobia and fear projected from the heart of the empire outwards. 
If we really want to change the dangerous trend of global repression, we must change it here first. For only then can the world breathe a deep sigh of relief.

C Copyright 2006 Mumia Abu-Jamal. Read Mumia's latest book, "We Want Freedom: A Life in the Black Panther Party," winner of the 2005 People's Choice Award, available from South End Press, www.southendpress.org or (800) 533-8478. Keep updated by reading Action Alerts at www.mumia.org and www.moveorg.net. To download Mp3s of Mumia's commentaries, visit www.prisonradio.org or www.fsrn.org. Encourage the media to publish and broadcast Mumia's commentaries to inspire progressive movement and help call attention to his case. Send our brotha some love and light at: Mumia Abu-Jamal, AM 8335, SCI-Greene, 175 Progress Dr., Waynesburg PA 15370.Contact Dr. Sumchai at (415) 835-4763 or asumchai@sfbayview. com 


\section{Legal Update and Latest Brief on Mumia Attorney Robert Bryan}

On July 20, 2006 we filed the Brief of Appellee and Cross Appellant, Mumia Abu-Jamal, in the US Court of Appeals for the Third Circuit, Philadelphia (Abu-Jamal v. Horn, U.S. Ct. of Appeals Nos. 01-9014, 02-9001). This brief is of great significance concerning my client's right to a fair trial, due process of law, not to be subjected to cruel and unusual punishment, and equal protection of the law, guaranteed by the Fifth, Sixth, Eighth and Fourteenth Amendments to the U.S. Constitution. The issues the court is hearing are:

Claim 14 Whether Mr. Abu-Jamal was denied the right to due process of law and a fair trial because of the prosecutor's "appeal-after-appeal" argument which encouraged the jury to disregard the presumption of innocence and reasonable doubt, and err on the side of guilt.

Claim 16 Whether the prosecution's exclusion of African Americans from sitting on the jury violated Mr. Abu-Jamal's rights to due process and equal protection of the law, and contravened Batson v. Kentucky, 476 U.S. 79 (1986).

Claim 25 Whether the verdict form and jury instructions that resulted in the death penalty deprived Mr. Abu-Jamal of the right to due process of law, equal protection of the law, and not to be subjected to cruel and unusual punishment, and violated Mills v. Maryland, 486 U.S. 367 (1988), since the judge precluded the jurors from considering any mitigating evidence unless they all agreed on the existence of a particular circumstance.

Claim 29 Whether Mr. Abu-Jamal was denied due process and equal protection of the law during post-conviction hearings as the result of the bias and racism of Judge Albert F. Sabo which included the comment that he was "going to help "em fry the nigger".

The National Lawyers Guild, and, the NAACP Legal Defense and Educational Fund, Inc., will be filing separate amicus curiae (friend of the court) briefs in the near future. This should strengthen our quest to see justice done.

It is a is a remarkable accomplishment that the court is hearing issues that go to the very essence of Mr. Abu-Jamal's right to a fair trial. This is 
the first time that any court has made a ruling that could lead to a new trial and freedom. Nevertheless, he remains on Pennsylvania's death row and in great danger.

Mr. Abu-Jamal, the "voice of the voiceless," is a powerful symbol in the international campaign against the death penalty and for human rights. The goal of Professor Judith L. Ritter, associate counsel, and I is to see that the many wrongs which have occurred in this case are righted and that this brave man is freed. 